\title{
Adulterants in crack cocaine in Brazil
}

\author{
Adulterantes no crack vendido na "Cracolândia"
}

\author{
Marcelo Ribeiro, ${ }^{1,2,3}$ Alisson Paulino Trevizol, ${ }^{1}$ (D) Rosana Frajzinger, ${ }^{1}$ Ariadne Ribeiro, ${ }^{1}$ (D) \\ Hannelore Speierl, ${ }^{4}$ Luciana Pires, ${ }^{3}$ Maristela Andraus, ${ }^{5}$ Lolita Tsanaclis, ${ }^{5,6}$ Ana Leonor Sala Alonso, ${ }^{7}$ \\ Quirino Cordeiro, ${ }^{3}$ Ronaldo Laranjeira ${ }^{3}$
}

\begin{abstract}
Introduction: Brazil is the world's biggest consumer of crack cocaine, and dependence is a major public health issue. This is the first study to investigate the prevalence of potentially harmful adulterants present in hair samples from Brazilian patients with crack cocaine dependence.

Method: We evaluated adulterants in hair samples extracted by convenience from 100 patients admitted at the 48 hourobservation unit of Centro de Referência de Álcool, Tabaco e Outras Drogas (CRATOD), Brazil's largest center for addiction treatment. A cross-sectional analysis was performed with the data obtained.

Results: Adulterants were found in $97 \%$ of the analyzed hair samples. The most prevalent adulterant was lidocaine (92\%), followed by phenacetin (69\%) and levamisole (31\%).

Conclusion: Adulterants were widely prevalent in hair samples from crack users treated at CRATOD: at least one adulterant was present in virtually all the hair samples collected. This points to a need to monitor adverse effects in the clinical setting in order to provide this high-risk group of patients with prompt and effective care related to the acute and chronic complications associated with these adulterants.
\end{abstract}

Keywords: Cocaine, crack cocaine, adulterants, substance use disorders, toxicology.

\section{Resumo}

Introdução: O Brasil é o maior consumidor mundial de crack, e a dependência é um grande problema de saúde pública. Este é o primeiro estudo a investigar a prevalência de adulterantes potencialmente nocivos presentes em amostras de cabelo de pacientes brasileiros com dependência de crack.

Métodos: Foram avaliados adulterantes em amostras de cabelos extraídos por conveniência de 100 pacientes internados na unidade de observação de 48 horas do Centro de Referência de Álcool, Tabaco e Outras Drogas (CRATOD), o maior centro de tratamento de dependência do Brasil. Uma análise transversal foi realizada com os dados obtidos.

Resultados: Foram encontrados adulterantes em 97\% das amostras de cabelo analisadas. $\mathrm{O}$ adulterante mais prevalente foi a lidocaína (92\%), seguida da fenacetina (69\%) e levamisol (31\%).

Conclusão: Os adulterantes foram amplamente prevalentes em amostras de cabelo de usuários de crack tratados no CRATOD: pelo menos um adulterante estava presente em praticamente todas as amostras de cabelo coletadas. Isso aponta para a necessidade de monitorar os efeitos adversos no ambiente clínico, a fim de proporcionar a esse grupo de pacientes de alto risco cuidados imediatos e efetivos relacionados às complicações agudas e crônicas associadas a esses adulterantes.

Descritores: Crack, cocaína, transtornos por uso de substâncias, toxicologia.

${ }^{1}$ Centro de Referência de Álcool, Tabaco e Outras Drogas (CRATOD), Secretaria de Saúde do Estado de São Paulo, São Paulo, SP, Brazil. ${ }^{2}$ Universidade Nove de Julho (UNINOVE), São Paulo, SP, Brazil. ${ }^{3}$ Departamento de Psiquiatria, Universidade Federal de São Paulo (UNIFESP), São Paulo, SP, Brazil. ${ }^{4}$ Unidade Recomeço Helvétia, Associação Paulista para o Desenvolvimento da Medicina, São Paulo, SP, Brazil. ${ }^{5}$ Laboratório Chromatox, São Paulo, SP, Brazil. ${ }^{6}$ Cansford Laboratories, Cardiff, United Kingdom. ${ }^{7}$ Programa Recomeço, Secretaria da Saúde, Governo do Estado de São Paulo, São Paulo, SP.

Submitted Dec 08 2017, accepted for publication Aug 272018.

Suggested citation: Ribeiro M, Trevizol AP, Frajzinger R, Ribeiro A, Speierl H, Pires L, et al. Adulterants in crack cocaine in Brazil. Trends Psychiatry Psychother. 2019;41(2):186-190. http://dx.doi.org/10.1590/2237-6089-2017-0143 


\section{Introduction}

Crack cocaine dependence is a significant public health issue in Brazil, which is the world's largest consumer of crack cocaine ${ }^{1-5}$; in 2013, the lifetime and one-year prevalence of crack cocaine dependence were estimated at 1.5 and $0.8 \%$, respectively. ${ }^{6}$ Most of the cocaine and crack cocaine traded contains adulterants and diluents in variable proportions. Some adulterants have similar effects to cocaine or are used to enhance the effect of the drug and reduce the amount of cocaine used, thus reducing production costs and maximizing profit. ${ }^{7}$

The most popular adulterants present in crack cocaine are caffeine, lidocaine, phenacetin, levamisole, benzocaine, procaine and hydroxyzine. ${ }^{7-10}$ Here we present an evaluation of adulterants present in hair samples from patients admitted to Centro de Referência de Álcool, Tabaco e Outras Drogas (CRATOD), affiliated with the State Department of Health of the State of São Paulo. CRATOD is the largest center for addiction treatment in Brazil. It is located in the surroundings of "Cracolândia," an area in the city of São Paulo, Brazil, in which crack cocaine is openly traded and consumed. Although other studies have looked into adulterants present in samples of cocaine confiscated in Brazil, this is the first study to evaluate the absorption of such substances by Brazilian crack cocaine users.

\section{Methods}

We used a cross-sectional design in a convenience sample. Hair samples were collected from patients admitted to CRATOD, considering the following eligibility criteria: being 18 years old or older; having been brought to the service from "Cracolândia" between June and December $2014(n=100)$; and having signed an informed consent form as determined by the institutional review board at CRATOD.

Hair samples were stored and analyzed at Laboratório Chromatox. Samples were collected from the posterior vertex region during the first 48 hours of observation. All samples were analyzed for cocaine, benzoylecgonine, cocaethylene, hydroxyzine, lidocaine, procaine, benzocaine, tetrahydrocannabinol (THC), phenacetin and levamisole, following the methods previously described by Tsanaclis \& Wicks, ${ }^{11}$ using 10 to $20 \mathrm{mg}$ of hair, alkaline hydrolysis, and solid phase extraction. The analyses were performed using liquid chromatography-mass spectrometry (Agilent, Santa Clara, U.S.).

\section{Results}

The sample comprised 100 patients admitted to CRATOD for the treatment of crack cocaine addiction.

Adulterants were present in $97 \%$ of the hair samples. All the samples resulted positive for cocaine and benzoylecgonine, $94 \%$ for cocaethylene and $23 \%$ for THC. The most prevalent adulterant was lidocaine $(92 \%)$, followed by phenacetin $(69 \%)$ and levamisole $(31 \%)$. Other adulterants found were benzocaine $(19 \%)$, procaine $(5 \%)$ and hydroxyzine $(2 \%)$. The sample could be classified into 13 groups on the basis of adulterants present in the hair samples (Figure 1). The most common combination was phenacetin and lidocaine, followed by lidocaine only.

Table 1 - Sociodemographic profile of crack cocaine users $(n=100)$ submitted to hair analysis at CRATOD, São Paulo, Brazil, from May to December 2018

\begin{tabular}{|c|c|}
\hline Variable & n (\%) \\
\hline Mean age (years), mean (SD) & $29.3(8.56)$ \\
\hline \multicolumn{2}{|l|}{ Age range (years) } \\
\hline$\leq 20$ & $16(16)$ \\
\hline $21-30$ & $43(43)$ \\
\hline $31-40$ & $31(31)$ \\
\hline$\geq 41$ & $10(10)$ \\
\hline \multicolumn{2}{|l|}{ Gender } \\
\hline Male & 49 (49) \\
\hline Female & $36(36)$ \\
\hline Transgender & $15(15)$ \\
\hline \multicolumn{2}{|l|}{ Race } \\
\hline White & $36(36)$ \\
\hline Afro-Brazilian & $64(64)$ \\
\hline \multicolumn{2}{|l|}{ Civil status $(n=96)$} \\
\hline Single & $53(55.2)$ \\
\hline Married & $15(15.6)$ \\
\hline Divorced & $26(27.1)$ \\
\hline Widow & $2(2.1)$ \\
\hline \multicolumn{2}{|l|}{ Schooling $(n=92)$} \\
\hline$<8$ years & $70(76)$ \\
\hline$\geq 8$ years & $22(24)$ \\
\hline \multicolumn{2}{|l|}{ Homeless } \\
\hline Yes & $73(73)$ \\
\hline No & $27(27)$ \\
\hline \multicolumn{2}{|l|}{ Currently working $(n=94)$} \\
\hline Yes & $34(36.2)$ \\
\hline No & $60(63.8)$ \\
\hline
\end{tabular}

Data presented as $\mathrm{n}(\%)$, unless otherwise specified. CRATOD = Centro de Referência de Álcool, Tabaco e Outras Drogas. 


\section{Discussion}

The large body of research available on adulterants and diluents present in cocaine has provided robust evidence of their use and its clinical consequences. A study carried out in the Netherlands ${ }^{12}$ found that $40.6 \%$ of their cocaine samples contained adulterants, and the most common were benzocaine, caffeine, lidocaine, levamisole, diltiazem, procaine, atropine and phenacetin. In 9,681 samples collected in Spain between 1985 and 1987, lidocaine was the main adulterant, present in $69.6 \%$. Conversely, lidocaine was absented from samples collected between 1992 and 1993, with caffeine being the most prevalent adulterant. ${ }^{13}$ Fucci \& De Giovanni investigated the composition of 156 samples collected in Rome between 1996 and 1997 and found 14 different adulterants, including lidocaine (16.5\% in 1996 and $12.3 \%$ in 1997), caffeine (11\% in 1997 and $6.1 \%$ in 1997$)$ and phenacetin $(6.7 \%$ in 1997) in the illicit cocaine market. ${ }^{14}$

Following these initial studies, a collaboration called the Trans-European Drug Information (TEDI) project was launched. This combined the consumer-targeted drug testing systems of the European Union with data from Spain, Switzerland, Austria, the Netherlands, Brussels, and Portugal and found differences in terms of the purity and composition of drugs. Several adulterants were found in illicit cocaine, with levamisole being the most commonly detected adulterant in 2013, followed by phenacetin and caffeine. ${ }^{10}$

In the U.S., the Drug Enforcement Administration (DEA) reported that in $20042-20 \%$ of cocaine samples contained hydroxyzine and $8-20 \%$ contained diltiazem. ${ }^{15}$ The first report of levamisole as an adulterant in the U.S. was by the DEA in $2005,{ }^{15}$ and it is now routinely found in cocaine samples. Since the early studies, the reported prevalence of adulteration of cocaine with levamisole, diltiazem or hydroxyzine has increased from $6.5 \%$ in 1999 to $53.6 \%$ in $2007 .{ }^{16}$
In Brazil, studies performed in the state of Minas Gerais reported that $72 \%$ of samples were less than $20 \%$ pure, with caffeine, lidocaine, benzocaine, and prilocaine being the most common adulterants in cocaine. ${ }^{17}$ In the state of São Paulo, Carvalho \& Mídio reported that lidocaine, procaine, and caffeine were the main adulterants in 389 samples of cocaine confiscated in 1997.7 Maldaner et al. reported that phenacetin was presented in $30 \%$ of 210 samples seized in various Brazilian states; they also found levamisole, caffeine and lidocaine. ${ }^{18}$

Levamisole was originally developed in the 1960s as an antihelminthic agent; it has immuno-stimulant properties that increase endogenous opiate levels and alter monoaminergic function - these effects may be responsible for its popularity as a cocaine adulterant. In in vivo research using the conditioned place preference paradigm to investigate the combination of cocaine and levamisole showed a marked synergistic effect. ${ }^{10}$ Levamisole is also very cheap, so using it as an adulterant substantially increases profit. It has also been postulated that levamisole acts as a monoamine oxidase inhibitor and increases dopamine transmission. Aminorex, a psychoactive metabolite of levamisole, has a potent amphetamine-like effect on dopamine and norepinephrine transporters. ${ }^{19,20}$ Because the halflife of aminorex far exceeds that of cocaine, combining levamisole with cocaine may prolong the duration of the stimulant effects. ${ }^{20}$

Because of its immunomodulatory effects, levamisole has been used to treat immune-mediated and inflammatory disorders, such as rheumatoid arthritis, nephritic syndrome, inflammatory bowel disease, aphthous ulcers and colon cancer. ${ }^{21-24}$ As a result, one of the most severe consequences of the adulteration of cocaine with levamisole is leukoencephalopathy. Xu et al. speculated that levamisole could cause acute and recurrent white matter lesions. ${ }^{25}$ There are previous reports of cases related to the presence of levamisole

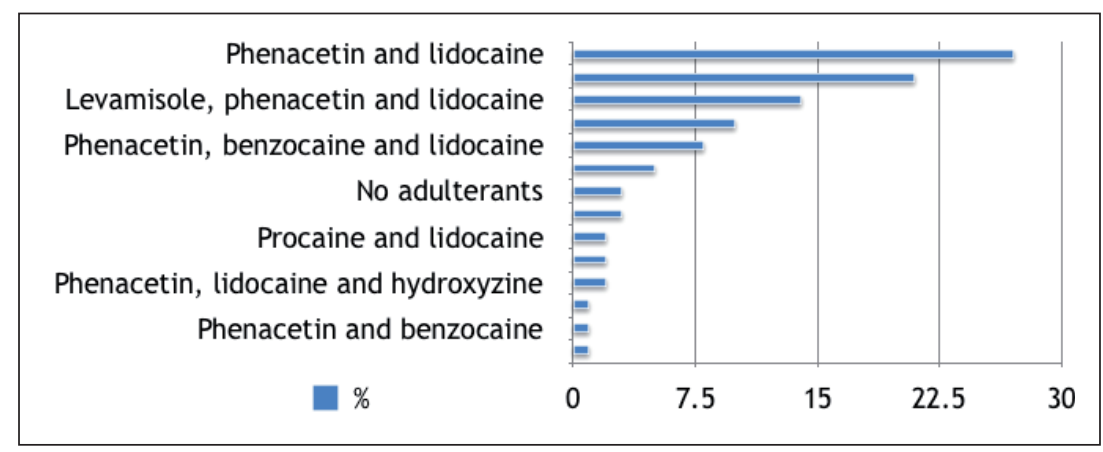

Figure 1 - Grouping of patients based on adulterants present in hair samples 
in urine and blood. ${ }^{26,27}$ Leukoencephalopathy is similar to other spongiform encephalopathies in which fluid is trapped in small vacuoles within the myelin lamellae. Findings from magnetic resonance imaging (MRI) include hyper-intense T2 and FLAIR signals, abnormality in the diffusion-weighted signal, gadolinium enhancement and/or surrounding edema. ${ }^{21,25,28}$ White matter lesions are typically found in subcortical and periventricular white matter, but can involve the brainstem and cerebellum. ${ }^{28} \mathrm{~A}$ brain biopsy can demonstrate loss of myelin and accumulation of perivascular lymphocytes. ${ }^{28}$ Other clinical consequences, such as neutropenia, agranulocytosis, and dermatological disorders, have also been reported. ${ }^{29}$

Since the first case of agranulocytosis was described by Buchanan in 2010, there have been multiple case reports of severe agranulocytosis after chronic abuse of cocaine and crack cocaine. ${ }^{10}$ Cutaneous and thrombotic vasculopathy associated with the use of levamisoleadulterated cocaine is more prevalent in female users and is characterized by pronounced retiform purpura with cutaneous necrosis, which can lead to serious deformations and may require amputation. ${ }^{29}$ It has previously been hypothesized that there is a synergistic relationship, or cross-sensitization, between cocaine and levamisole, and cocaine alone has been linked to necrotizing granulomatous vasculitis and Churg-Strauss vasculitis. ${ }^{30}$

Another severe complication of chronic cocaine abuse, related to adulteration of cocaine with phenacetin and local anesthetics, is methemoglobinemia, 31,32 which can lead to severe hypoxemia, seizures, coma, and death. This blood disorder is characterized by the presence of circulating methemoglobin in erythrocytes, resulting in reduced tissue oxygen due to a reduction of the oxygen-carrying ability of erythrocytes, and an increased affinity for oxygen in non-affected heme molecules, which impairs the off-loading of oxygen to the tissues.

At least one adulterant was present in $97 \%$ of the hair samples analyzed in the present study, most often local anesthetics, phenacetin and levamisole. The widespread presence of adulterants in hair samples may be due to the use of crack cocaine from multiple sources, although our sample usually consumed the drug in the vicinity of "Cracolândia."

Our findings should be considered in light of the limitations of the study, such as its cross-sectional design, reliance on a single center and the small sample size. Further prospective studies of the consequences of the widespread presence of crack cocaine adulterants in hair samples should be performed, in order to provide a clearer picture of their public health impact.
This is the first study of the presence of potentially harmful adulterants in hair samples from Brazilian patients with crack cocaine dependence. On the basis of the prevalence of adulterants in the hair samples of users from "Cracolândia," we conclude that there is a need to monitor adverse effects in the clinical setting in order to provide this high-risk group of patients with prompt and effective care.

\section{Disclosure}

No conflicts of interest declared concerning the publication of this article.

\section{References}

1. Ribeiro M, Dunn J, Laranjeira R, Sesso R. High mortality among young crack cocaine users in Brazil: a 5-year follow-up study. Addiction. 2004;99:1133-5.

2. Ribeiro M, Dunn J, Sesso R, Dias AC, Laranjeira R. Causes of death among crack cocaine users. Rev Bras Psiquiatr. 2006;28:196202.

3. Duailibi LB, Ribeiro M, Laranjeira R. Profile of cocaine and crack users in Brazil. Cad Saude Publica. 2008;24 Suppl 4:s545-57.

4. Ribeiro M, Duailibi S, Frajzinger R, Alonso AL, Marchetti L, Williams AV, et al. Abuse and addiction: crack. Rev Assoc Med Bras. 2012;58:141-53.

5. Ribeiro $M$, Duailibi $S$, Frajzinger $R$, Alonso $A L$, Marchetti $L$, Williams AV, et al. The Brazilian "Cracolandia" open drug scene and the challenge of implementing a comprehensive and effective drug policy. Addiction. 2016;111:571-3.

6. Abdalla RR, Madruga CS, Ribeiro M, Pinsky I, Caetano R, Laranjeira R. Prevalence of cocaine use in Brazil: data from the II Brazilian national alcohol and drugs survey (BNADS). Addict Behav. 2014;39:297-301.

7. Carvalho DG de, Mídio AF. Quality of cocaine seized in 1997 in the street-drug market of São Paulo city, Brazil. Rev Bras Cienc Farm. 2003;39:71-5.

8. Tanner-Smith EE. Pharmacological content of tablets sold as "ecstasy": results from an online testing service. Drug Alcohol Depend. 2006;83:247-54.

9. United Nations Development Programme; Human Development Reports [Internet]. [cited Dec 05 2017]. http://hdr.undp.org/en/ composite/HDI

10. Brunt TM, Nagy C, Bucheli A, Martins D, Ugarte M, Beduwe C, et al. Drug testing in Europe: monitoring results of the Trans European Drug Information (TEDI) project. Drug Test Anal. 2017;9:188-98.

11. Tsanaclis L, Wicks JFC. Differentiation between drug use and environmental contamination when testing for drugs in hair. Forensic Sci Int. 2008;176:19-22.

12. Brunt TM, Rigter S, Hoek J, Vogels N, van Dijk P, Niesink RJ. An analysis of cocaine powder in the Netherlands: content and health hazards due to adulterants. Addiction. 2009;104:798-805.

13. Barrio G, Saavedra P, de la Fuente L, Royuela L. Purity of cocaine seized in Spain, 1985-1993: variations by weight, province and year of seizure. Forensic Sci Int. 1997;85:15-28.

14. Fucci N, De Giovanni N. Adulterants encountered in the illicit cocaine market. Forensic Sci Int. 1998;95:247-52.

15. Cole C, Jones L, McVeigh J, Kicman A, Syed Q, Bellis M. Adulterants in illicit drugs: a review of empirical evidence. Drug Test Anal. 2011;3:89-96.

16. Buchanan JA, Oyer RJ, Patel NR, Jacquet GA, Bornikova L, Thienelt $C$, et al. A confirmed case of agranulocytosis after use of cocaine contaminated with levamisole. J Med Toxicol. 2010;6:160-4.

17. Magalhaes EJ, Nascentes CC, Pereira LS, Guedes ML, Lordeiro RA, Auler LM, et al. Evaluation of the composition of street cocaine seized in two regions of Brazil. Sci Justice. 2013;53:425-32. 
18. Maldaner AO, Botelho ÉD, Zacca JJ, Melo RCA, Costa JL, Zancanaro I, et al. Chemical profiling of street cocaine from different Brazilian regions. J Braz Chem Soc. 2016;27:719-26.

19. Chang A, Osterloh J, Thomas J. Levamisole: a dangerous new cocaine adulterant. Clin Pharmacol Ther. 2010;88:408-11.

20. Hofmaier T, Luf A, Seddik A, Stockner T, Holy M, Freissmuth M, et al. Aminorex, a metabolite of the cocaine adulterant levamisole, exerts amphetamine like actions at monoamine transporters. Neurochem Int. 2014;73:32-41.

21. Cheng YC, Po HL. Leukoencephalopathy after levamisole for the treatment of verrucae. Acta Neurol Taiwan. 2011;20:262-6.

22. Abeyagunawardena AS, Karunadasa $U$, Jayaweera $H$, Thalgahagoda S, Tennakoon S, Abeyagunawardena S. Efficacy of higher-dose levamisole in maintaining remission in steroiddependant nephrotic syndrome. Pediatr Nephrol. 2017;32:1363-7.

23. Collister D, Sathianathan $C$, Ryz K, Karpinski M, Bernstein K Gibson IW. ANCA-associated vasculitis secondary to levamisoleadultered cocaine with associated membranous nephropathy: A case series. Am J Nephrol. 2017;45:209-16.

24. Hernandes MR, Moraes LC, Ribeiro EB, Fagundes DL, HonorioFranca AC, Franca EL. In vitro immunomodulatory effects of microemulsions with levamisole delivery systems on blood phagocytes interacting with Giardia lamblia. Parasitol Int. 2017;66:299-304

25. Xu N, Zhou W, Shuy L, Zhou G, Zhang N. Clinical and MRI characteristics of levamisole-induced leukoencephalopathy in 16 patients. J Neuroimaging. 2009;13:326-31.

26. Bianco F, Iacovelli E, Tinelli E, Lepre C, Pauri F. Recurrent leukoencephalopathy in a cocaine abuser. Neurotoxicology. 2011;32:410-2.
27. Gonzalez-Duarte A, Williams R. Cocaine-induced recurrent leukoencephalopathy. Neuroradiol J. 2013;26:511-3.

28. Vosoughi R, Schmidt BJ. Multifocal leukoencephalopathy in cocaine users: a report of two cases and review of the literature. BMC Neurol. 2015;15:208.

29. Larocque A, Hoffman RS. Levamisole in cocaine: unexpected news from an old acquaintance. Clin Toxicol. 2012;50:231-41.

30. Gertner E, Hamlar D. Necrotizing granulomatous vasculitis associated with cocaine use. J Rheumatol. 2002;29:1795-7.

31. McKinney CD, Postiglione KF, Herold DA. Benzocaine-adultered street cocaine in association with methemoglobinemia. Clin Chem. 1992;38:596-7.

32. Chakladar A, Willers JW, Pereskokova E, Beaumont PO, Uncles DR. White powder, blue patient: methaemoglobinaemia associated with benzocaine-adulterated cocaine. Resuscitation. 2010;81:138-9.

\section{Correspondence:}

Alisson Paulino Trevizol

Centro de Referência de Álcool, Tabaco e Outras Drogas (CRATOD)

Secretaria de Saúde do Estado de São Paulo

Rua Prates, 165, Bom Retiro

01120-001 - São Paulo, SP - Brazil

Tel.: +55 (11) 33294455

E-mail: alisson.trevizol@hotmail.com 